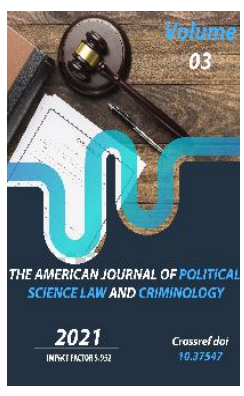

\title{
Ethno-Political Aspects Of The Kurdish Problem: An Analysis Of Different Approaches
}

\author{
Fotima Nazarova
}

2nd Year Student, Tashkent State University Of Oriental Studies, Uzbekistan

Journal Website: https://theamericanjou rnals.com/index.php/ta jpslc

Copyright: Original content from this work may be used under the terms of the creative commons attributes 4.0 licence.

\section{ABSTRACT}

This article discusses the Kurdish problem, its actuality, some ethno-political aspects of the problem, the existence of different, sometimes contradictory approaches to issues related to the Kurds, as well as international legal aspects of the problem. The article focuses on the fact that the Kurdish problem is not only a regional problem in terms of ethno-politics, but also a comprehensive problem at the international level. It is revealed that the ethno-political issue related to the Kurds is being assessed on the basis of controversial and mutually exclusive approaches.

\section{KEYWORDS}

Kurds, Kurdistan, ethno-political problems, PKK, New Middle East, Khoybun, Iraqi Kurdistan, "Great Kurdistan".

\section{INTRODUCTION}

Today, the Kurds are considered to be one of the largest nations who do not possess their own independent statehood in the world. Analysts and researchers attempt to study this problem as an ethno-political problem. Another subtle aspect of the issue is that the Kurds remain as a geopolitical problem that affects the territorial integrity of regional actors such as Turkey, Iran, Syria and Iraq, and ultimately the architecture of the entire Middle East. In turn, this problem has a serious impact on the balance of power in world politics, increasing the likelihood that it will become a global problem. Indeed, any radical change related to the Kurds alone could become a factor in the complete revival of large and numerous ethnic groups that do not have their own state all over the world. From this point of 
view, there is a need for in-depth study of this issue, the development of in-depth scientific research, substantiated debates on its ethnopolitical aspects.

The purpose of the article is to reveal the ethno-political aspects of the Kurdish problem. In view of the goal, views on the Kurdish problem, the influence of major and regional powers, and the justification of international legal aspects of the problem were identified as tasks.

Methods: Historical, structural-logical, content and comparative methods are used in the article.

\section{THE MAIN FINDINGS AND RESULTS}

It should be noted that research or books on the Kurdish issue have been conducted on the basis of different approaches, and this process continues due to some political and national interests. The versatility of this research is closely related to its different assessments by Western, Russian, Turkish, and Arab scholars. The history of the origin of the Kurdish ethnos, its peculiarities, the Kurdish national movement, the role of the Kurds in the sociopolitical processes in the region, the relationship of external forces with the Kurds, the work on approaches to solving the Kurdish problem is covered in detail in the works of such specialists as David McDowall, Martin van Bruinessen, Wadie Jwaideh, Michael Gunter, Jemal Nebez, Karen Culcasi, Michael Eppel, John Limbert, Henri Barkey, Graham Fuller, P.Olson, Basil Nikitin, Radwan Ziadeh, Mehrdad Izady, Robin Mills, Works by Connor, Gareth Stansfield and others, Ziya Gökalp, Ali Rıza Sheikh Attar, Mehmet Akbaş, Ihsan Şerif Kaymaz, Bekir Bicer, Taha Özen, Hatem Ete,
Ahmet Buran, Faik Bulut, Nihat Ali Özcan, Ulrike Dufner, Semahat Sevim, Abdur in Turkey Qasimlo, Fatih Ünal, Yılmaz A. Octav Özden Zeynep, Fuat Aksu, Hüseyin Alptekin and M.S. Lazarev, Tibet Abak, M.V. Gladyr, M.A. Gasratyan, O.I. Jigalina, Xoshavi Babakr, S.M Ivanov, N.Z. Mosaki, O. Mazur (Karimov, 2021, p.8.). Abdullah Ocalan, the founder of the Kurdistan Workers' Party (PKK), who fought for an independent Kurdish state, also has a book entitled "The Kurdish Problem and the Solidarity of the Democratic Nation Model: Protecting the Kurds Trapped in Cultural Genocide" (Ocalan, 2016). In this book, the author details the origins, life and activities of the Kurds, the Kurdistan Workers' Party and its ideological foundations, and the decisive role of the Kurds in the history of the Middle East.

It is clear that when we talk about the conflicts in the Middle East, two extremely important factors come to mind: the religious and ethnic factor. Naturally, the conflicts that reflect the main picture of ethno-religious factors in the region are the Arab-Israeli conflict and the Kurdish problem. The Kurdish issue, like the Arab-Israeli conflict, is a long-unresolved issue that has not been studied in depth.

The Kurds are one of the oldest and most numerous ethnic groups in the Middle East who have not been able to have their own independent state in the world. The total number of Kurds, according to the latest data, is about 30-40 million. $47-54 \%$ (about 15 million) of Kurds live in Turkey, 20-32\% (6.6 million) in Iran, 16-20\% (6 million) in Iraq, and the rest in other countries (2.8 million in Syria). 800,000 in Germany, 150,000 in Azerbaijan, 100,000 in Israel, 10,000 in Lebanon, 40,000 in Turkmenistan, and 20,000 in the United States (Karimov, 2016, p.107-108). 
At the heart of the Kurdish problem is the fact that for centuries the aspirations of the Kurds to have their own independent state have been denied by both regional and international forces. The Kurds have already caught the attention of the international community by demanding their cultural, social and political recognition and trying to establish their own independent state in a region divided between the four states.

The solution of the Kurdish problem of regional significance is hampered by the fact that each country has different policies towards the Kurds in its territory, and in turn, the diversity of ideas and actions of the Kurds in each country towards a separate state. One of the main reasons why the Kurdish problem is still going on is that Kurdish leaders in the 20th and 21st centuries have taken different paths for liberation movements (some have chosen militancy, some have chosen the diplomatic path). Well-known Kurdish orientalist and diplomat Vasily Nikitin lists three stages of the Kurdish national movement in his fundamental work called "The Kurds" (Nikitin, 1964, p.284-285). The first stage began with the revolt of the feudal lords, disobedience, social coups, while the second stage coincided with the revolution of the young Turks, who fought for their national identity. The third phase began after the First World War (the Treaties of Sevres and Lausanne) when the Kurdish problem became an international problem. According to the scholar, when Kurdish National Committee (Hoybun) formed in 1927, it became the first institutional structure to coordinate the Kurdish national movement. The current phase of the Kurdish national movement began in 2003 with the invasion of American forces to Iraq, followed by the establishment of an autonomous region of
Iraqi Kurdistan and its acquisition of certain powers.

Another noteworthy aspect is that the analysis of the geographical location and population prospects is of particular importance in understanding the Kurdish problem. If Kurdistan is unified as a whole, its land area will exceed 500,000 square kilometers. In other words, Kurdistan will become an equal state with France, not a district or province. In short, the Kurdish problem is not a problem of ethnic minorities in any country, but a hot regional problem in the Middle East. Another root cause of the problem is geographical location. In turn, the geographical factor is divided into geocultural, geoeconomic and geopolitical factors. These four factors play a major role in a deeper understanding of the Kurdish problem (Stefano, 2016, p.22-23).

First, the Kurds have sufficient basis to claim Kurdistan territory. They have lived in this area for two thousand years. That is why they are constantly fighting to have their own state.

Second, the geo-cultural factor also plays an important role in the escalation of the conflict. The Kurds are ethnically and culturally completely different from the Turks and the Arabs. They have their own language, as well as distinct currents in religious beliefs. The same factors have been cited by the Kurds as the basis for an independent state. These factors, in turn, have led to the development of conflicts with the governments of Kurdishpopulated countries.

The third factor is the geo-economic factor. Kurdistan is needed by Turkey and Arab countries for oil and gas reserves. That is why the four states do not want to lose Kurdistan. 
In this regard, it is necessary to mention Iraq. The reason is that a number of embargoes and sanctions were imposed on the country's economy before the US invasion of Iraq. With the exception of Iraqi Kurdistan, the region was essential for Iraq's economic recovery after the overthrow of Saddam Hussein.

Finally, the last factor is the geopolitical factor. We have seen above that the Middle Eastern states do not want to lose control of the region. On the other hand, the Kurds have their own political problems. There are various political forces whose views on Kurdish political life contradict each other. These political forces are not unanimous in resolving the Kurdish issue. After all, the Kurds themselves are politically divided into two, but even more confrontational, and above all, the issue of solving their own internal problems arises. Meanwhile, the Kurdish factor by major power centers could serve as a major weapon and tool for those seeking leadership in the Middle East. Geopolitically, this issue is particularly evident in the so-called "New Middle East" concept of the United States. Although a number of forces pursue geopolitical goals by supporting the Kurdish struggle for national independence, Kurdish movements in various locations intend to be independent from external forces. They say, "The Kurds have no friends, only mountains" (Peter W.Galbrataith, 2016). All Kurds except for the Kurds in Syria are mountain peoples. At a time of increasing pressure on them, Kurdish resistance movements carried out operations mainly from the mountains. Therefore, such statements are common among them.

States in the region have always been concerned that the Kurdish independence could destabilize the situation in their own countries and in the region, and that the territorial unit could be torn apart. Therefore, in order to maintain their territorial units, the governments of the region have been trying to suppress the Kurdish movement by force. The radical actions of the Kurds further complicate the problem. Iraq's pursuit of full independence is also a serious concern for Kurdish neighbors. Some analysts predict that the Kurds in Iraq may be the backbone of the Kurdish state-building process. In Turkey, the Kurds are demanding an amendment to the existing constitution, which would establish the Kurdistan Autonomy within the Republic of Turkey. This is not in the interests of Turkey, which pursues the idea of a "single state" (Van Bruinessen, Martin, 1996, p.29-32). On the other hand, the "Great Kurdistan" ideology of the Kurds, which has become more active in Syria in recent years, is of serious concern to Syria and its government, which are already divided. The situation in Iran is very different from that of the Kurds living in the rest of the region. It should be noted that today the Kurds do not have enough influence to affect the territorial integrity of this state.

At the same time, another serious problem is the lack of a unified approach to ethno-political issues in international law. In particular, on the one hand, the principle of self-determination of peoples and nations, on the other hand, the principle of territorial integrity of the state contradicts each other. For example, in the case of the Kurds, Turkey, Syria, Iraq, and Iran prioritize the principle of territorial integrity, while they take the first principle as their basis. Most notably, from an international legal point of view, Kurdish organizations are seen by some quarters as separatist or terrorist groups, while in some cases they are seen as a nation fighting for their freedom. For example, Turkey 
has listed the PKK as a terrorist organization, calling its activists terrorists. PKK militants tried to hinder the development of the tourism business in Turkey by blowing up hotels and kidnapping foreign tourists. According to Turkish special services, Kurdish terrorists are not seeking a peaceful confrontation. PKK activists are carrying out the same terrorist acts in Turkey. PKK is also known as an organization that organizes self-immolation of Kurds in different parts of the world (Goyibnazarov, 2013, p.87. In some cases, external forces other than the Kurds themselves, particularly the United States, have been seen as financially and militarily supporting Kurdish forces in various parts of the Middle East as a national movement. This requires serious consideration by the international community that the existing legal approaches to ethno-political issues will be a factor that will complicate the current situation.

\section{CONCLUSION}

There is ample reason to say that the Kurdish problem is an ethno-politically complex problem not only regionally but also internationally. It is important to understand that the Kurds have long been divided into four states, and that they are fighting for their independence in the same regions. In addition, it is the fact that these struggling processes of the Kurds are being turned into an important tool for their geopolitical goals by certain forces, and the lack of a unified international legal approach and mechanism on ethnopolitical issues, makes it necessary to study this problem carefully and find a constructive solution.

\section{REFERENCES}

1. Goyibnazarov Sh. International terrorism: roots, factors and sources. (in Uzbek) Tashkent: Uzbekistan, 2013. - P.87.

2. Karimov F.E. The Kurdish factor in ethnopolitical processes in the Middle East. Abstract of the dissertation of Doctor of Political Sciences (DSc). (in Uzbek). Tashkent: 2021. - p.8.

3. Karimov F.E.. Ethno-political problems in the Middle East and regional security issues. (in Uzbek) -Tashkent.: "Sharq", 2016. - p.107-108.

4. Nikitin V. Kurds. (In Russian). - Moscow. 1964. - p.284-285.

5. Ocalan A. Manifesto of a Democratic Society. Book Five: The Kurdish problem and the solution to the model of a democratic nation: Protecting the Kurds, we are in the grip of cultural genocide. Moscow: Federal national-cultural autonomy of the Kurds of the Russian Federation. (in Russian) - Moscow: 2016. $832 \mathrm{pp}$.

6. Peter W.Galbrataith. The end of Iraq: How American Incompetence Created a War Without End. Simon \& Schuster, 2006.

7. Stefano M. Torelli. Kurdistan An Invusible Nation. ISPi., 2016. - p. 22-23.

8. Van Bruinessen, Martin. 'Diversity and division among the Kurds', Warreport, Bulletin of the Institute for War and Peace Reporting, o 47. 1996. - p. 29-32. 